\title{
Pengelompokan Dan Klasifikasi Pada Data Hepatitis Dengan Menggunakan Support Vector Machine (SVM), Classification And Regression Tree (Cart) Dan Regresi Logistik Biner
}

\author{
Gede Suwardika ${ }^{1, *}$ \\ 1 Universitas Terbuka, UPBJJ-UT Denpasar
}

\begin{abstract}
Abstrak
Hepatitis adalah peradangan pada hati karena toxin, seperti kimia atauobat ataupun agen penyebab infeksi. Hepatitis yang berlangsung kurang dari 6 bulan disebut "hepatitis akut", hepatitis yang berlangsung lebih dari 6 bulan disebut "hepatitis kronis".Hepatitis biasanya terjadi karena virus, terutama salah satu dari kelima virus hepatitis, yaitu $A, B, C, D$ atau E. Hepatitis juga bisa terjadi karena infeksi virus lainnya, seperti mononukleosis infeksiosa, demam kuning dan infeksi sitomegalovirus. Penyebab hepatitis non-virus yang utama adalah alkohol dan obat-obatan.Dalam penelitian ini dilakukan tes terhadap 155 pasien dengan respon meninggal atau hidup. Untuk itu penerapan Data Mining akan dilakukan pada kasus diatas, memanfaatkan salah satu teknik yaitu Data Classification, sejumlah data testing yang tersedia akan di analisis serta dibandingkan dengan data training untuk dilakukan prediksi meninggal atau hidup.Hasil ketepatan klasifikasi antara data training dengan data testing dengan analisis regresi logistik adalah 79,4\% sedangkan dengan menggunakan SVM diperoleh sebesar $80 \%$. Pengelompokan dengan menggunakan K-Means dan Kernel K-Means menghasilkan ketepatan pengelompokan yang berbeda. Ini menunjukkan bahwa data hepatitis memiliki pengelompokan yang baik. Kemudian hasil pengelompokan pada Kernel K-Means dibandingkan dengan data aktual yang diklasifikasikan dengan menggunakan regresi logistik, SVM dan CART dimana dihasilkan bahwa data hasil dari Kernel K-Means memiliki ketepatan klasifikasi yang lebih baik dibandingkan dengan hasil klasifikasi pada data aktual.
\end{abstract}

Keywords:

Regresi Logistik Biner, SVM, Kernel K-Means, $K$ Means, CART.

\section{Pendahuluan}

Penyakit Hepatitis adalah penyakit yang disebabkan oleh beberapa jenis virus yangmenyerang dan menyebabkan peradangan serta merusak sel-sel organ hatimanusia. Hepatitis diketegorikan dalam beberapa golongan, diantaranya hepatitis A,B,C,D,E,F dan G. Di Indonesia penderita penyakit Hepatitis umumnya cenderung lebih banyak mengalami golongan hepatitis B dan hepatitis $C$, namun disini kita akan membahas pada hidup atau matai pada penyakit Hepatitis, data diambil langsung dari website http://archive.ics.uci.edu/ml/datasets.html (UCI Machine Learning Repository)

Masalah klasifikasi banyak dijumpai dalam kehidupan sehari-hari seperti dalam penentuan diterima atau tidaknya pengajuan kredit dalam bidang perbankan, hingga diagnosis suatu penyakit di bidang kedokteran. Klasifikasi merupakan salah satu bentuk peramalan yang memiliki nilai keluaran diskrit, dan bertujuan untuk menemukan suatu fungsi keputusan $\mathrm{f}(\mathrm{x}) \mathrm{yang}$ secara akurat memprediksi kelas dari data (Santosa, 2007). Pola data dipelajari dengan pendekatan supervised learning untuk memprediksi data berikutnya yang memiliki kemiripan. Dalam pendekatan ini, label keluaran telah dikelompokkan, sehingga fungsi pemisah antara label satu dengan lainnya dapat dicari dengan mempelajari data kelas-kelas yang telah ada untuk mengklasifikasi data baru. Data yang digunakan untuk melatih fungsi disebut datatraining, sedangkan data untuk menguji model disebut data testing.

Dalam data mining dan machine learning telah dikembangkan berbagai metode klasifikasi2 seperti analisis diskriminan (linear discriminantanalysis), decision tree, Artificial Neural Networks, hingga Support Vector Machines (SVM). Pada beberapa penelitian, metode SVM telah terbukti mampu melakukan klasifikasi dengan baik untuk berbagai kasus. Menurut Frie, et. al., pencarian hyperplane dengan menggunakan program kuadratik SVM memiliki kelemahan yakni proses komputasi yang berat, berakibat pada waktu komputasiyang panjang.

Data Mining merupakan salah satu solusi yang dapat diterapkan untuk permasalahan data diatas. Data Mining itu sendiri adalah serangkaian proses yang dilakukan pada sejumlah data besar untuk diolah 
dan dihasilkan informasi yang lebih berguna, disiplin ilmu ini mengkaji berbagai metode yang umum digunakan untuk melakukan pengolahan data tersebut, salah satu metode pengolahan dalam prosesnya adalah klasifikasi data.

Klasifikasi data biasa digunakan pada sejumlah data yang telah di ketahui data induknya, untuk kemudian dijadikan data training/data model yang hasilnya akan menjadi keputusan prediksi dari sejumlah data yang serupa namun belum lengkap pada salah satu atributnya. Support Vector Machines (SVM) adalah sistem learning yang menggunakan sebuah ruang hipotesis fungsi linier dalam ruang fitur berdimensi tinggi, dilatih dengan menggunakan sebuah algoritma pembelajar dari teori optimasi yang mengimplementasikan sebuah bias learnig yang diturunkan dari teori learning statistika. Strategi learning yang diperkenalkan oleh Vapnik dan timnya merupakan sebuah metode yang powerful dalam beberapa tahun sejak diperkenalkan dan telah melebihi sistem yang lain dalam berbagai aplikasi.

Konsep dasar SVM adalah: (1) Class Separation, pada dasarnya, SVM mencari bidang hyperplane yang memisahkan secara optimal antara dua kelas dengan memaksimalkan margin antara titik terdekat kelas tersebut. Pada Gambar 1, terlihat bahwa titik yang berada pada batas dinamakan support vectors, dan bagian tengah margin merupakan bidang hyperplane yang memisahkan secara optimal. (2) Overlapping Classes, titik-titik data pada sisi "salah" dari diskriminan margin diturunkan untuk mengurangi pengaruhnya (soft margin). (3) Non Linearity, ketika tidak dapat ditemukan pemisah berbentuk linier, titik-titik data biasanya diproyeksikan ke dalam ruang dimensi yang lebih tinggi dimana titik-titik data secara efektif akan menjadi pemisah linier (proyeksi ini direaliasikan melalui teknik kernel). Dan (4) Problem Solution, semua tugas tersebut dapat diformulasikan sebagai permasalahan optimasi quadratik yang dapat diselesaikan dengan teknik yang diketahui.

\section{Metode Penelitian}

Data yang digunakan Hipatitis yang berasal dari UCI Machine Learning Repository. Variabelvariabel yang digunakan adalah: Class: DIE, LIVE, AGE: 10, 20, 30, 40, 50, 60, 70, 80, SEX: male, female, STEROID: no, yes, ANTIVIRALS: no, yes, FATIGUE: no, yes, MALAISE: no, yes, ANOREXIA: no, yes, LIVER BIG: no, yes, LIVER FIRM: no, yes, SPLEEN PALPABLE: no, yes, SPIDERS: no, yes, ASCITES: no, yes, VARICES: no, yes, BILIRUBIN: 0.39, 0.80, 1.20, 2.00, 3.00, 4.00, ALK PHOSPHATE: 33, 80, 120, 160, 200, 250, SGOT: 13, 100, 200, 300, 400, 500, ALBUMIN: 2.1, 3.0, 3.8, 4.5, 5.0, 6.0, PROTIME: 10, 20, 30, 40, 50, 60, 70, 80, 90, HISTOLOGY: no, yes.

Langkah-langkah yang dilakukan dalam penelitian ini yaitu: (1) engevaluasi data hepatitis apakah terdapat missing value. Kemudian setelah diketahui missing value yang besar pada variable, tetapi pada data ini variabel-variabel yang diketahui missing value tidak dihapus,tetapi tetap digunakan dengan cara dengan cara mengganti data pada variabel-variabel yang missing value tersebut menggunakan nilai mean. (2) Mengklasifikasikan data dengan menggunakan analisis regresi logistik biner. (3) Mengklasifikasikan data menggunakan SVM dengan bantuan software Matlab setelah sebelumnya membagi data menjadi 116 data training dan 39 data sebagai testing. (4) Pembandingan ketepatan klasifikasi antara analisis regresi logistik dan SVM. (5) Mengklasifikasikan dengan menggunakan K-Means dan Kernel K-Means kemudian menentukan hasil prediksi terbaik yang mendekati data aktual. Dan (6) Data aktual diklasifikasikan menggunakan analisis regresi logistik, SVM dan CART kemudian membandingkan hasilnya. Hasil prediksi terbaik pada langkah 7 diklasifikasikan menggunakan analisis regresi logistik, SVM dan CART kemudian membandingkan hasilnya.

\section{Preprocessing Data Missing Value}

\section{Analisis dan Pembahasan}

Missing value adalah informasi yang tidak tersedia untuk sebuah objek (kasus).Missing value terjadi karena informasi untuk sesuatu tentang objek tidak diberikan,sulit dicari, atau memang informasi tersebut tidak ada.Missing value pada dasarnya tidak bermasalah bagi keseluruhan data, apalagi jikajumlahnya hanya sedikit, misal hanya $1 \%$ dari seluruh data. Namun jika persentasedata yang hilang tersebut cukup besar, maka perlu dilakukan pengujian apakah datayang mengandung banyak missing tersebut masih layak diproses lebih lanjut ataukahtidak. Cara lain dalam penanganan missing value yaitu: menghilangkan/membuang kasus atau objek yang mengandung missing value dan menghapus variabel (kolom) yang mengandung missing value.

Pada tahap ini akan dilakukan pengevaluasian terhadap banyaknya missing value. Variabel X19(PROTIME) memiliki banyak missing value yaitu sebesar 43,2\%, karena dari 20 variabel yang digunakan ada 15 variabel yang missing value, tetapi disini tidak ada yang dihilangkan, data missing value 
tetap digunakan dengan cara mengganti data pada variabel-variabel yang missing value tersebut menggunakan nilai mean.

Tabel 1. Univariate Statistics

\begin{tabular}{|c|c|c|c|c|c|c|c|}
\hline & \multirow{2}{*}{$\mathrm{N}$} & \multirow{2}{*}{ Mean } & \multirow{2}{*}{ Std. Deviation } & \multicolumn{2}{|c|}{ Missing } & \multicolumn{2}{|c|}{ No. of Extremes ${ }^{a}$} \\
\hline & & & & Count & Percent & Low & High \\
\hline $\mathrm{v} 2$ & 155 & 41.2000 & 12.56588 & 0 & .0 & 0 & 1 \\
\hline v15 & 149 & 1.4275 & 1.21215 & 6 & 3.9 & 0 & 17 \\
\hline v16 & 126 & 105.3254 & 51.50811 & 29 & 18.7 & 0 & 5 \\
\hline v17 & 151 & 85.8940 & 89.65089 & 4 & 2.6 & 0 & 13 \\
\hline v18 & 139 & 3.8173 & .65152 & 16 & 10.3 & 1 & 1 \\
\hline v19 & 88 & 61.8523 & 22.87524 & 67 & 43.2 & 0 & 0 \\
\hline $\mathrm{v} 1$ & 155 & & & 0 & .0 & & \\
\hline v3 & 155 & & & 0 & .0 & & \\
\hline $\mathrm{v} 4$ & 154 & & & 1 & .6 & & \\
\hline v5 & 155 & & & 0 & .0 & & \\
\hline v6 & 154 & & & 1 & .6 & & \\
\hline v7 & 154 & & & 1 & 6 & & \\
\hline v8 & 154 & & & 1 & .6 & & \\
\hline v9 & 145 & & & 10 & 6.5 & & \\
\hline v10 & 144 & & & 11 & 7.1 & & \\
\hline v11 & 150 & & & 5 & 3.2 & & \\
\hline v12 & 150 & & & 5 & 3.2 & & \\
\hline v13 & 150 & & & 5 & 3.2 & & \\
\hline v14 & 150 & & & 5 & 3.2 & & \\
\hline v20 & 155 & & & 0 & .0 & & \\
\hline
\end{tabular}

a. Number of cases outside the range (Q1 - $1.5 * \mathrm{IQR}, \mathrm{Q} 3+1.5 * \mathrm{IQR})$.

Pada beberapa variabel dan observasi yang memiliki missing value dengan persentase kecil, maka kekosongan nilai dapat diisi dengan mean yang diperoleh dari masing-masing variable seperti pada Tabel dibawah ini :

Tabel. Statistics

\begin{tabular}{|c|c|c|c|c|c|c|c|c|c|c|c|c|c|c|c|c|}
\hline & & $\mathrm{v} 4$ & v6 & v7 & v8 & v9 & v10 & v11 & v12 & v13 & v14 & v15 & v16 & v17 & v18 & v19 \\
\hline \multirow{4}{*}{$\left.\right|_{\text {Mean }} ^{\text {N }}$} & Valid & 154 & 154 & 154 & 154 & 145 & 144 & 150 & 150 & 150 & 150 & 149 & 126 & 151 & 139 & 88 \\
\hline & $\begin{array}{l}\text { Missin } \\
\mathbf{g}\end{array}$ & 1 & 1 & 1 & 1 & 10 & 11 & 5 & 5 & 5 & 5 & 6 & 29 & 4 & 16 & 67 \\
\hline & & 1.50 & 1.35 & 1.603 & 1.792 & 1.82 & 1.58 & 1.800 & 1.660 & 1.86 & 1.880 & 1.427 & 105.325 & \multirow{2}{*}{85.8940} & \multirow{2}{*}{3.8173} & 61.852 \\
\hline & & 65 & 06 & 9 & 2 & 76 & 33 & 0 & 0 & 67 & 0 & & 4 & & & \\
\hline
\end{tabular}

Tabel. Statistika Deskriptif Masing-masing Variabel

\begin{tabular}{|l|r|r|r|r|r|r|}
\hline & $\mathrm{N}$ & Minimum & Maximum & \multicolumn{1}{c|}{ Mean } & Std. Deviation & Variance \\
\hline Class & 155 & 1,00 & 2,00 & 1,7935 &, 40607 &, 165 \\
Age & 155 & 20,00 & 78,00 & 41,6065 & 12,47100 & 155,526 \\
Sex & 155 & 1,00 & 2,00 & 1,1032 &, 30524 &, 093 \\
Steroid & 155 & 1,00 & 2,00 & 1,5065 &, 49996 &, 250 \\
Antivirals & 155 & 1,00 & 2,00 & 1,8452 &, 36292 &, 132 \\
Fatigue & 155 & 1,00 & 2,00 & 1,3506 &, 47717 &, 228 \\
Malaise & 155 & 1,00 & 2,00 & 1,6039 &, 48909 &, 239 \\
Anorexia & 155 & 1,00 & 2,00 & 1,7922 &, 40573 &, 165 \\
LiverBig & 155 & 1,00 & 2,00 & 1,8276 &, 36654 &, 134 \\
LiverFirm & 155 & 1,00 & 2,00 & 1,5833 &, 47673 &, 227 \\
SpleenPalpable & 155 & 1,00 & 2,00 & 1,8000 &, 39477 &, 156 \\
Spider & 155 & 1,00 & 2,00 & 1,6600 &, 46752 &, 219 \\
Ascites & 155 & 1,00 & 2,00 & 1,8667 &, 33549 &, 113 \\
Varices & 155 & 1,00 & 2,00 & 1,8800 &, 32071 &, 103 \\
Balirubin & 155 &, 30 & 8,00 & 1,4275 & 1,18830 & 1,412 \\
AlkPhosphate & 155 & 26,00 & 295,00 & 105,3254 & 46,40558 & 2153,478 \\
Sgot & 155 & 14,00 & 648,00 & 85,8940 & 88,47893 & 7828,521 \\
Albumin & 155 & 2,10 & 6,40 & 3,8173 &, 61675 &, 380
\end{tabular}




\begin{tabular}{|l|r|r|r|r|r|r|} 
Protime & 155 &, 00 & 100,00 & 61,8523 & 17,19353 & 295,617 \\
Histology & 155 & 1,00 & 2,00 & 1,4516 &, 49927 &, 249 \\
Valid N (listwise) & 155 & & & & & \\
\hline
\end{tabular}

Tabel. Case Processing Summary

\begin{tabular}{|ll|r|r|}
\hline \multicolumn{2}{|l|}{ Unweighted Cases $^{\mathrm{a}}$} & $\mathrm{N}$ & \multicolumn{1}{c|}{ Percent } \\
\hline \multirow{3}{*}{ Selected Cases } & Included in Analysis & 155 & 100,0 \\
\cline { 2 - 4 } & Missing Cases & 0 &, 0 \\
Unselected Cases & Total & 155 & 100,0 \\
Total & 0 &, 0 \\
\hline
\end{tabular}

a. If weight is in effect, see classification table for the total number of cases.

Dependent Variable
Encoding
\begin{tabular}{|l|r|}
\hline Original Value & Internal Value \\
\hline DIE & 0 \\
LIVE & 1 \\
\hline
\end{tabular}

Block 0: Beginning Block

Tabel. Classification Tablea,b

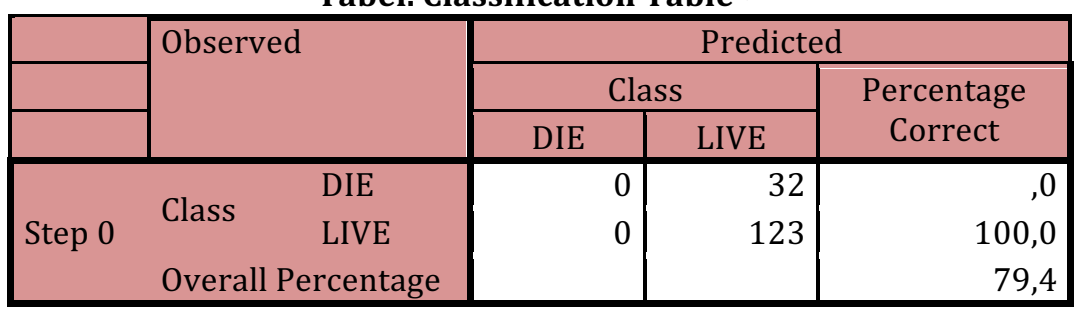

a. Constant is included in the model.

b. The cut value is ,500

Variables in the Equation

\begin{tabular}{|c|c|c|c|c|c|c|c|}
\hline & & B & S.E. & Wald & $\mathrm{df}$ & Sig. & $\operatorname{Exp}(B)$ \\
\hline Step 0 & Constant & 1,346 & ,198 & 46,037 & 1 &, 000 & 3,844 \\
\hline
\end{tabular}

Variables not in the Equation

\begin{tabular}{|ll|r|r|r|}
\hline \multicolumn{1}{|l|}{ Variables not in the Equation } & Score & df & \multicolumn{1}{c|}{ Sig. } \\
\hline & Age & 6,491 & 1 &, 011 \\
& Sex & 4,642 & 1 &, 031 \\
& Steroid & 2,808 & 1 &, 094 \\
& Antivirals & 2,627 & 1 &, 105 \\
& Fatigue & 14,800 & 1 &, 000 \\
& Malaise & 17,663 & 1 &, 000 \\
Step 0 & Anorexia & 2,703 & 1 &, 100 \\
& Variables &, 808 & 1 &, 369 \\
& LiverBig &, 534 & 1 &, 465 \\
& LiverFirm & 8,556 & 1 &, 003 \\
& SpleenPalpable & 23,816 & 1 &, 000 \\
& Spider & 34,282 & 1 &, 000 \\
& Ascites & 20,423 & 1 &, 000 \\
& Varices & 31,453 & 1 &, 000 \\
& Balirubin & 3,082 & 1 &, 079 \\
& AlkPhosphate &, 885 & 1 &, 347
\end{tabular}




\begin{tabular}{|c|r|r|r|}
\hline Albumin & 33,634 & 1 &, 000 \\
Protime & 14,631 & 1 &, 000 \\
Histology & 17,693 & 1 &, 000 \\
Overall Statistics & 73,670 & 19 &, 000 \\
\hline
\end{tabular}

Block 1: Method = Enter

Omnibus Tests of Model Coefficients

\begin{tabular}{|rl|r|r|r|}
\hline & & Chi-square & \multicolumn{1}{c|}{ df } & \multicolumn{1}{c|}{ Sig. } \\
\hline \multirow{4}{*}{ Step 1 } & Step & 85,246 & 19 &, 000 \\
& Block & 85,246 & 19 &, 000 \\
& Model & 85,246 & 19 &, 000 \\
\hline
\end{tabular}

Model Summary

\begin{tabular}{|l|r|r|r|}
\hline Step & $\begin{array}{c}-2 \text { Log } \\
\text { likelihood }\end{array}$ & $\begin{array}{c}\text { Cox \& Snell R } \\
\text { Square }\end{array}$ & $\begin{array}{c}\text { Nagelkerke R } \\
\text { Square }\end{array}$ \\
\hline 1 & $72,611^{\mathrm{a}}$ &, 423 &, 662 \\
\hline
\end{tabular}

a. Estimation terminated at iteration number 20 because maximum iterations has been reached. Final solution cannot be found.

\begin{tabular}{|c|c|c|c|c|c|}
\hline \multicolumn{6}{|c|}{ Classification Table } \\
\hline & \multirow{3}{*}{\multicolumn{2}{|c|}{ Observed }} & \multicolumn{3}{|c|}{ Predicted } \\
\hline & & & \multicolumn{2}{|c|}{ Class } & \multirow{2}{*}{$\begin{array}{c}\text { Percentage } \\
\text { Correct }\end{array}$} \\
\hline & & & DIE & LIVE & \\
\hline \multirow{3}{*}{ Step 1} & & DIE & 23 & 9 & 71,9 \\
\hline & & LIVE & 7 & 116 & 94,3 \\
\hline & Overa & ercentage & & & 89,7 \\
\hline
\end{tabular}

a. The cut value is ,500

Variables in the Equation

\begin{tabular}{|c|c|c|c|c|c|c|c|}
\hline & & B & S.E. & Wald & $\mathrm{df}$ & Sig. & $\operatorname{Exp}(B)$ \\
\hline \multirow{20}{*}{ Step $1^{\mathrm{a}}$} & Age &,- 056 & 030 & 3,386 & 1 & ,066 & ,946 \\
\hline & Sex & 21,244 & 8055,172 & , 000 & 1 & 998 & $\begin{array}{r}1682796751,7 \\
86\end{array}$ \\
\hline & Steroid & 1,223 & 834 & 2,150 & 1 & 143 & 3,398 \\
\hline & Antivirals &,- 065 & 1,158 & ,003 & 1 & ,955 & 937 \\
\hline & Fatigue & 776 & 1,081 & ,516 & 1 & 473 & 2,173 \\
\hline & Malaise & 539 & 914 & 347 & 1 & 556 & 1,714 \\
\hline & Anorexia & $-2,196$ & 1,012 & 4,703 & 1 & 030 & 111 \\
\hline & LiverBig & $-1,056$ & 1,093 & 933 & 1 & ,334 & 348 \\
\hline & LiverFirm &,- 813 & 901 & 814 & 1 & ,367 & ,444 \\
\hline & SpleenPalpable & 031 & 898 & 001 & 1 & ,972 & 1,032 \\
\hline & Spider & 2,413 & ,854 & 7,974 & 1 & ,005 & 11,164 \\
\hline & Ascites & 1,284 & 1,108 & 1,344 & 1 & 246 & 3,612 \\
\hline & Varices & 908 & 1,004 & 818 & 1 & 366 & 2,480 \\
\hline & Balirubin &,- 745 & 340 & 4,794 & 1 & ,029 & 475 \\
\hline & AlkPhosphate &,- 002 & ,007 & ,057 & 1 & 812 & 998 \\
\hline & Sgot &,- 001 & 004 & 051 & 1 & 821 & 999 \\
\hline & Albumin & 986 & ,746 & 1,746 & 1 & 186 & 2,679 \\
\hline & Protime & 022 & 024 & 874 & 1 & 350 & 1,023 \\
\hline & Histology & 458 & 804 & ,325 & 1 & ,569 & 1,581 \\
\hline & Constant & $-25,656$ & 8055,174 & ,000 & 1 & 997 & ,000 \\
\hline
\end{tabular}


a. Variable(s) entered on step 1: Age, Sex, Steroid, Antivirals, Fatigue, Malaise, Anorexia, LiverBig, LiverFirm, SpleenPalpable, Spider, Ascites, Varices, Balirubin, AlkPhosphate, Sgot, Albumin, Protime, Histology.

Interpretasi Hasil :

- Tabel dependen variable enconding menunjukkan variabel Class diberi kode $1=$ LIVE dan $2=$ DIE

- $\quad$ Output block : 0 beginning block

1. Classification table menunjukkan tabel $2 \times 2$ dengan kolom berupa predicted values dari variabel dependen dan baris berupa nilai data aktual yang diamati. Untuk model yang sempurna, semua cases akan terletak pada diagonal tabel dan overall percentage akan bernilai $100 \%$. Jika model regresi logistic mempunyai variance sama, maka nilai persen (\%) padakedua baris hampir sama. Overall percentage yang memprediksi model dengan benar mempunyai nilai cukup baik sebesar $\frac{132}{155} \times 100 \%-79,4 \%$

2. Tabel variables in the equation yang hanya berisi constant memberikan nilai $b_{0}=1,346$ atau $\exp (1,346)=e^{1,346}=3,844$. Karena responden yang mempunyai penyakit hepatitis dengan keadaan hidup (LIVE) ada 132 dan dengan keadaan mati (DIE) rendah ada 32, maka odd ratio = $\frac{32}{132}=0,2424$.

3. Uji wald pada tabel variables in the equation digunakan untuk menguji apakah masing-masing koefisien regresi logistik signifikan. Uji wald sama dengan kuadrat dari rasio koefisien regresi logistic B dan standar error S.E . dalam kasus ini uji wald :

$=\left[\frac{B}{S . E}\right]^{2}=\left[\frac{1,346}{0,198}\right]^{2}=46.21252933 . P$-value $=0,000$ lebih kecil dari $\alpha=0,05$.

Maka kesimpulannya constant dari model regresi logistic ini signifikan.

- $\quad$ Pada output block 1 : method enter

1. Tabel omnibus test of model coefficients memberikan nilai chi-square goodness-of-fit test sebesar 85,246 dengan derajat kebebasan $=19, P$-value $=0,000$ lebih kecil dari $\alpha=0,05$. sehingga hasil uji ini sngat signifikan, chi-square goodness-of-fit test disini digunakan untuk menguji hipotesis :

$H_{0}$ : memasukkan variabel independen ke dalam model tidak akan menambah kemampuan predeksi model regresi logistik

2. Tabel model summary memberikan nilai statistic $\mathbf{- 2}$ loglikehood $=\mathbf{7 2 , 6 1 1}$. semakin kecil nilai -2 loglikehood semakin baik.

3. Koefisien cox \& snall R square pada tabel model summary dapat diinterpretasikan sama seperti koefisien determinasi $R^{2}$ pada regresi berganda. Tetapi karena nilai cox \& snall R square biasanya lebih kecil dari 1 maka sukar untuk di interpretasikan dan jangan digunakan

4. Koefisien nagelkerkeR square pada tabel model summary merupakan modifikasi dari koefisiensi cox \& snall R square agar nilai maksimumnya bias mencapai satu dan mempunyai kisaran nilai antara 0 dan 1 , sama seperti koefisien determinasi $R^{2}$ pada regresi linear nerganda. Nilai koefisien nagelkerkeR square umumnya lebih besar dari koefisien cox \& snall R square tapi cenderung lebih kecil dibandingkan dengan nilai koefisien $R^{2}$ pada regrei linear berganda. Dalam contoh ini koefisien nagelkerkeR square $=0,662$.

5. Hasil perhitungan koefisien dari model regresi logistik biner ini terlihat pada tabel variables in the equation sebagai berikut :

In $\left(\frac{\pi}{1-\pi}\right)=-25,656-0,056$ Age $+21,244$ Sex $+1,223$ Steroid $-0,065$ Antivirals $+0,776$

Fatigue + 0,539 Malaise - 2,196 Anorexia - 1,056 LiverBig -0,813 LiverFirm + 0,031 SpleenPalpable $+2,413$ Spider $+1,284$ Ascites + 0,908 Varices $-0,745$ Balirubin $-0,002$ AlkPhosphate $-0,001$ Sgot $+0,986$ Albumin $+0,022$ Protime $+0,458$ Histology Atau $\frac{\pi}{1-\pi}=\exp (-$ 25,656 - 0,056 Age $+21,244$ Sex $+1,223$ Steroid $-0,065$ Antivirals + 0,776 Fatigue $+0,539$ Malaise - 2,196 Anorexia - 1,056 LiverBig -0,813 LiverFirm + 0,031 SpleenPalpable + 2,413 Spider + 1,284 Ascites + 0,908 Varices - 0,745 Balirubin - 0,002 AlkPhosphate - 0,001 Sgot + 0,986 Albumin + 0,022 Protime + 0,458 Histology)

6. Kolom $\operatorname{Exp(B)}$ merupakan odds ratio yang diprediksi oleh model, misalnya :
a. Untuk koefisien variabel Age :
$\exp (-0,056)=e^{-0,056}=0,946$
b. untuk koefisien variabel Sex :
$\exp (21,244)=e^{21,244}=1682796752$
c. Untuk constant : $(\exp -25,656)=e^{-25,656}=7,20677183 \mathrm{E}-12 \sim 0,000$

7. Uji wald manguji masing-masing koefisien regresi logistic, misalnya : 
a. Untuk koefisien variabel Age:

$=\left(\frac{B}{S . E}\right)^{2}=\left(\frac{-0,056}{0,030}\right)^{2}=3,386 . P$-value $=0,066$ lebih kecil dari $\alpha=0,05$, maka koefisien regresi untuk variabel Agetidak signifikan.

b. Untuk koefisien variabel Anorexia : $\left(\frac{-2,196}{1,012}\right)^{2}=4,703$. $P$-value $=0,030$ lebih kecil dari $\alpha=0,05$, maka koefisien regresi untuk variabel Anorexia signifikan.

c. Untuk Constant : $\left(\frac{-25,656}{8055,174}\right)^{2}=0,000 . P$-value $=0,997$ lebih besar dari $\alpha=0,05$, maka koefisien regresi untuk variabel constant tidak signifikan, artinya dari variabel-variabel prediktor, tidak semua variabel mempengaruhi LIVE dan DIE pada penyakit hepatitis.

\section{Support Vector Machine (SVM)}

SVM adalah suatu teknik yang relatif baru untuk melakukan prediksi, baik dalam kasus klasifikasi maupun regresi. Dalam hal ini data yang ingin diklasifikasikan adalah data echocardiogram. Dalam pengklasifikasian SVM ini ingin diketahui variabel y prediksi berdasarkan data training dan data testing, sehingga nantinya diketahui ketepatan y prediksi terhadap variabel y yang sebenarnya. Dengan bantuan program Matlab, didapatkan hasil seperti tabel berikut ini:

Tabel. Hasil Prediksi Y Dan Y Testing

\begin{tabular}{|c|c|c|c|c|}
\hline \multirow{2}{*}{$\begin{array}{c}\text { Data } \\
\text { Training }\end{array}$} & \multirow{2}{*}{$\begin{array}{c}\text { Data } \\
\text { Testing }\end{array}$} & \multicolumn{2}{|c|}{ Hasil Prediksi } & \multirow{2}{*}{$\begin{array}{l}\text { Ketepatan } \\
\text { Klasifikasi }\end{array}$} \\
\hline & & Sesuai & Tidak sesuai & \\
\hline 78 & 77 & 43 & 24 & $69 \%$ \\
\hline 116 & 39 & 25 & 14 & $64 \%$ \\
\hline 145 & 10 & 8 & 2 & $80 \%$ \\
\hline
\end{tabular}

Jadi ketepatan klasifikasi dengan SVM antara y prediksi dengan y testing yang terbaik adalah sebesar $80 \%$ dengan training sebanyak 145 dan 10 sebagai testing.

\section{K-Means dan Kernel K-Means}

Pengelompokan pada data hepatitis dengan menggunakan K-Means menghasilkan pengelompokan seperti pada tabel dibawah ini :

Tabel. Hasil Pengelompokan Menggunakan K-Means

\begin{tabular}{|c|c|c|}
\hline Kelas & TotalAktual & Hasil Pengelompokan \\
\hline-1 & 32 & 16 \\
\hline 1 & 123 & 139 \\
\hline
\end{tabular}

Dari hasil pengelompokan menggunakan K-Means, dapat dilihat bahwa sebanyak 16 data dikelompokkan dalam kelas pertama, sedangkan sisanya sebanyak 139 data dikelompokkan dalam kelas kedua.

Hasil yang didapatkan dari K-Means akan dibandingkan dengan kernel K-Means yang kemudian dibandingkan hasilnya untuk mendapatkan hasil pengelompokan terbaik yang mendekati data aktual. Dengan menggunakan kernel 'rbf'(Radial Basis Function) dan 'poly' menghasilkan error terkecil didapatkan hasil klasifikasi seperti pada Tabel dibawah ini :

Tabel. Hasil Pengelompokan Menggunakan Kernel K-Means

\begin{tabular}{|c|c|c|}
\hline Kelas & Total & Hasil Pengelompokan \\
\hline-1 & 32 & 22 \\
\hline 1 & 123 & 133 \\
\hline
\end{tabular}

Dapat dilihat bahwa dihasilkan pengelompokan yang sama persis. Gambar dibawah ini menunjukkan plot hasil pengelompokan dengan menggunakan metode kernel. Pada plot kernel dibandingkan dengan hasil kernel dengan error yang besar sebagai pembanding. 


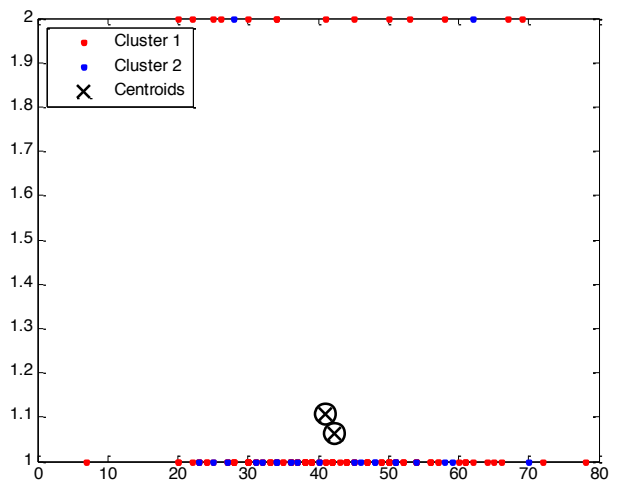

Gamba. Plot Hasil Pengelompokan Dengan K-Means

Klasifikasi Data Aktual dan Hasil K-Means Menggunakan Analisis Regresi Logistik, SVM dan CART

Pengklasifikasian pada data aktual berikut ini tanpa membagi data menjadi data testing dan data training dilakukan untuk mengetahui bagaimana hasil ketepatan klasifikasi dengan menggunakan analisis regresi logistik, SVM dan CART. Hasil pengklasifikasian dibandingkan dengan klasifikasi dengan menggunakan data hasil pengelompokan dengan menggunakan Kernel K-Means. Tabel dibawah ini, merupakan perbandingan hasil dengan menggunakan ketiga data dengan regresi logistik, SVM dan CART.

Tabel. PerbandinganKetepatan Klasifikasi

\begin{tabular}{|c|c|c|c|}
\hline \multirow{2}{*}{ Y } & \multicolumn{3}{|c|}{ Metode } \\
\cline { 2 - 4 } & Regresi Logistik & SVM & CART \\
\hline Data Aktual & $79,4 \%$ & $79,4 \%$ & $83,2 \%$ \\
\hline Hasil K-Means & $89,7 \%$ & $90,3 \%$ & $100 \%$ \\
\hline Hasil Kernel K-Means & $85,8 \%$ & $98,7 \%$ & $98,7 \%$ \\
\hline
\end{tabular}

Pengklasifikasian antara ketiga data dengan ketiga metode menghasilkan ketepatan klasifikasi dengan nilai yang besar. Pada data aktual, ketepatan klasifikasi terbesar adalah dengan menggunakan metode CART yaitu sebesar 83,2\%, sedangkan pada data hasil K-Means dihasil ketepatan sebesar $100 \%$ dengan menggunakan CART dan data hasil Kernel K-Means ketepatan sebesar 98,7\% dengan menggunakan metode SVM dan CART.

Berdasarkan tabel diatas dapat dilihat bahwa ketepatan klasifikasi ketiga data menggunakan ketiga metode menghasilkan ketepatan yang lebih besar dengan menggunakan data hasil dari Kernel K-Means. Hal ini dikarenakan data tersebut sudah merupakan hasil dari pengelompokan dengan metode K-Means, sehingga pengklasifikasian-nya akan lebih baik dibandingkan dengan data aktual.

\section{Kesimpulan}

Kesimpulan yang dapat dibuat berdasarkan hasil klasifikasi yang telah dilakukan adalah: Pada metode pengklasifikasian diperoleh bahwa hasil klasifikasi CART dan Pengklasifikasian dengan menggunakan K-Means dan Kernel K-Means menghasilkan ketepatan klasifikasi yang berbeda, yang mana dari kedua metode tersebut Kernel K-Means menunjukkan bahwa data hepatitis memiliki pengelompokan yang baik.

\section{Daftar Pustakan}

Agresti, A. 2007. An Introduction to Categorical Data Analysis Second Edition. USA : A John Wiley \& Sons, Inc.

D.C. Montgomery. 1991. Design and Analysis of Experiments, Third Edition. John Wiley \& Sons.

Gunn S. R. 1998. Support Vector Machines for Classification and Regression. TechnicalReport. University of Southampton. 
Johnson, R.A. and Winchern, D.W. 2007. Applied Multivariate Statistical Analysis. USA: Pearson Education International

Lim, T.S. 1997. Contraceptive Method Choice. http://archive.ics.uci.edu, diakses 6 April 2012.

Nancy, JA. 1999. Contraception : Present and Future. Medical Journal of Indonesia. Vol.8: No. 1.

Ratna M., Susilaningrum D. 2006. Buku Ajar Analisys Multivariat FMIPA-ITS Surabaya.

Ruslan, Mohammad. 2000.Pengelompokan Wilayah di Jawa Timur Berdasarkan Komponen Penyusun Indeks Kemiskinan Manusia Sesudah dan Sebelum Krisis Ekonomi.

Santosa, B. 2007. Data Mining : Teknik Pemanfaatan Data untuk Keperluan Bisnis. Yogyakarta : Graha Ilmu.

Sobirin. 2006. Mengenal Lebih Dalam Aneka Alat Kontrasepsi,http://www.kafka.web.id/forum/ kesehatan1, diakses 6 April 2012.

Santoso, Budi.2007. Data Mining Terapan dengan Matlab. Yogyakarta : Graha Ilmu

Santoso, Budi.2007. Teori \& Aplikasi Data Mining. Yogyakarta : Graha Ilmu

Trihendredi, Cornelius., 2005. Step by step SPSS 13 Analisis Data Statistik. Yogyakarta : ANDI

Http://archive.ics.uci.edu/ml/datasets.html (UCI Machine Learning Repository) 